\title{
Pharmacokinetics of the soluble guanylate cyclase stimulator riociguat in individuals with renal impairment
}

\author{
Reiner Frey ${ }^{1 *}$, Corina Becker ${ }^{1}$, Sigrun Unger ${ }^{2}$, Anja Schmidt ${ }^{1}$, Georg Wensing ${ }^{1}$, Wolfgang Mueck \\ From 6th International Conference on cGMP: Generators, Effectors and Therapeutic Implications \\ Erfurt, Germany. 28-30 June 2013
}

\section{Background}

Riociguat is the first oral, soluble guanylate cyclase stimulator under review for the treatment of pulmonary hypertension $(\mathrm{PH})$, a progressive, ultimately fatal disease [1-7]. This pooled analysis of two studies evaluated the pharmacokinetics of riociguat and its metabolite M1 (BAY 60-4552) in individuals with and without renal impairment. The safety and tolerability of riociguat were also assessed.

\section{Methods}

Two non-randomized, non-blinded, observational studies with group stratification were conducted in a single centre in Germany, following Good Clinical Practice and relevant industry guidelines $[8,9]$. Participants were assigned to one of four renal function groups according to their creatinine clearance $\left(\mathrm{CL}_{\mathrm{CR}}\right)$ : group $1, \mathrm{CL}_{\mathrm{CR}}>80 \mathrm{~mL} / \mathrm{min}$; group 2 , $\mathrm{CL}_{\mathrm{CR}} 50-80 \mathrm{~mL} / \mathrm{min}$; group $3, \mathrm{CL}_{\mathrm{CR}} 30-49 \mathrm{~mL} / \mathrm{min}$; group $4, \mathrm{CL}_{\mathrm{CR}}<30 \mathrm{~mL} / \mathrm{min}$. In the first study, individuals in group 4 received riociguat $0.5 \mathrm{mg}$; all other participants in both studies received riociguat $1 \mathrm{mg}$ (single tablet doses). Pharmacokinetic parameters were assessed using dense sampling.

\section{Results}

Sixty-three participants (40 men and 23 women; mean age, 61.3 years [range, $36-78$ years]) completed the study and were eligible for pharmacokinetic analysis. Riociguat was

Table 1 Pharmacokinetic parameters of riociguat in healthy participants and in individuals with mild, moderate or severe renal impairment

\begin{tabular}{|c|c|c|c|c|}
\hline Parameter & $\begin{array}{c}\text { Group } 1\left(\mathrm{CR}_{\mathrm{CL}}>80 \mathrm{~mL} / \mathrm{min}\right) \\
\mathrm{n}=16\end{array}$ & $\begin{array}{c}\text { Group } 2\left(\mathrm{CR}_{\mathrm{CL}} 50-80 \mathrm{~mL} / \mathrm{min}\right) \\
\mathrm{n}=15\end{array}$ & $\begin{array}{c}\text { Group } 3\left(\mathrm{CR}_{\mathrm{CL}} 30-49 \mathrm{~mL} / \mathrm{min}\right) \\
\mathrm{n}=16\end{array}$ & $\begin{array}{c}\text { Group } 4^{a}\left(C_{C L}<30 \mathrm{~mL} / \mathrm{min}\right) \\
n=16\end{array}$ \\
\hline$\overline{A \cup C}, \mu \mathrm{g} \cdot h / L$ & $245.7(51)$ & $347.5(111)$ & $499.0(110)$ & $523.0(70.4)^{b}$ \\
\hline$C_{\max ,} \mu \mathrm{g} / \mathrm{L}$ & $36.6(17)$ & $44.2(21)$ & $42.0(32)$ & $40.56(37.8)^{b}$ \\
\hline $\begin{array}{l}\mathrm{AUC}_{\text {norm }} \\
\mathrm{kg} \cdot \mathrm{h} / \mathrm{L}\end{array}$ & $20.6(56)$ & 29.4 (126) & 42.1 (109) & 29.7 (102) \\
\hline $\begin{array}{l}C_{\text {max,norm }}, \mathrm{kg} / \\
L\end{array}$ & 3.07 (17) & $3.48(25)$ & $3.54(30)$ & $2.97(40)$ \\
\hline$t_{1 / 2}, h$ & $6.19(50)$ & 10.1 (116) & 11.4 (103) & $9.52(75)$ \\
\hline
\end{tabular}

an the first study, individuals with severe renal impairment (group 4) received riociguat $0.5 \mathrm{mg}$; all other participants in both studies received riociguat 1 mg. ${ }^{b} A U C$ and $C_{\max }$ values shown for individuals with severe renal impairment (group 4 ) are taken from the second study ( $\mathrm{n}=8$ ), in which individuals with severe renal impairment received riociguat $1.0 \mathrm{mg}$.

Values are geometric means (percentage coefficient of variation). AUC, area under the plasma concentration-time curve from time 0 to infinity; $A \cup C_{\text {norm }}$ AUC divided by dose per kilogram of body weight for total riociguat; $C_{\max }$, maximum concentration in plasma; $C_{\max , \text { norm }}, C_{\max }$ divided by dose per kilogram of body weight for total riociguat; $\mathrm{t}_{1 / 2}$, terminal elimination half-life for total riociguat.

\footnotetext{
* Correspondence: reiner.frey@bayer.com

${ }^{1}$ Clinical Pharmacology, Bayer Pharma AG, Pharma Research Centre,

Wuppertal, Germany

Full list of author information is available at the end of the article
}

C Biomed Central

C 2013 Frey et al; licensee BioMed Central Ltd. This is an Open Access article distributed under the terms of the Creative Commons Attribution License (http://creativecommons.org/licenses/by/2.0), which permits unrestricted use, distribution, and reproduction in any medium, provided the original work is properly cited. 


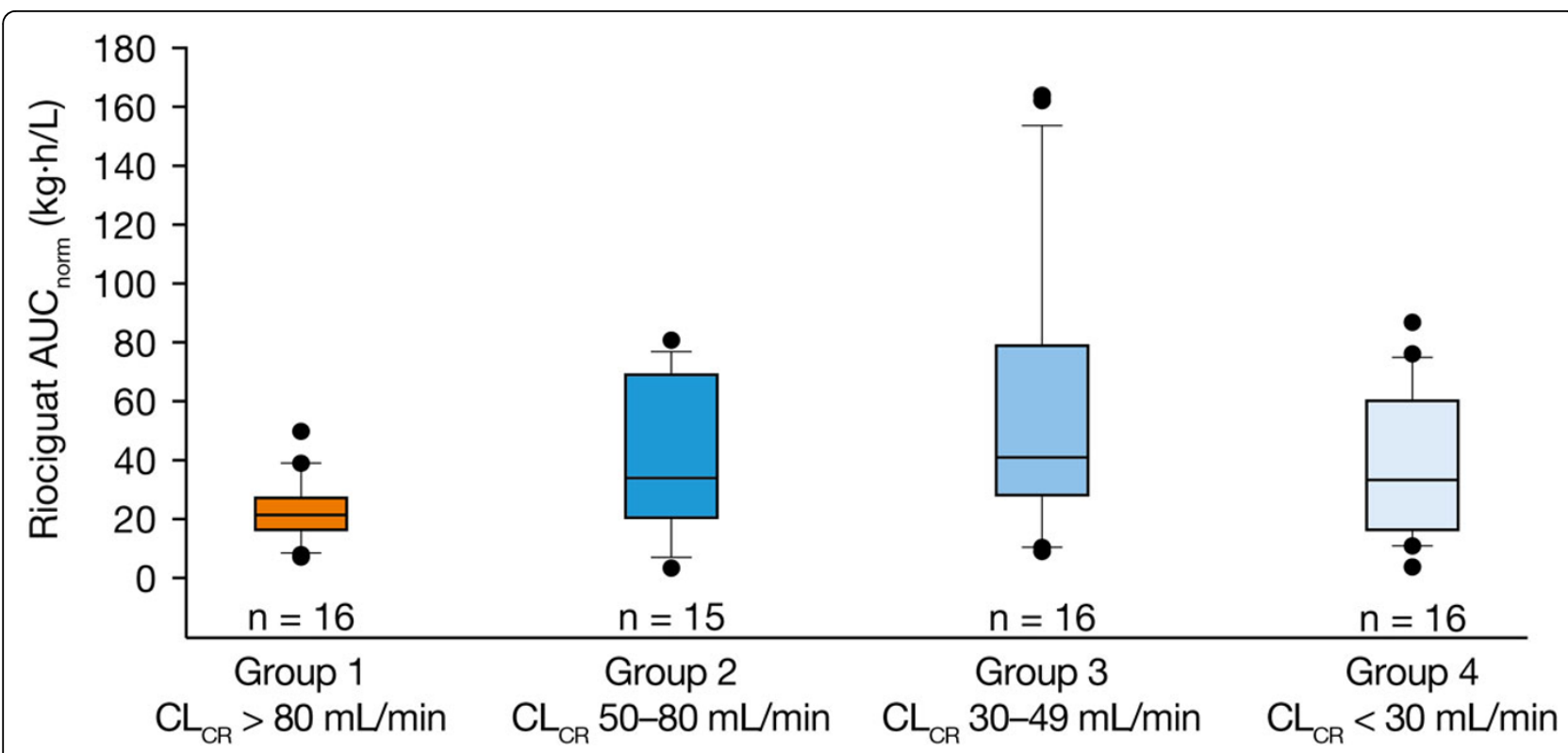

Figure 1 Box-and-whisker plot of riociguat $A \cup C_{n o r m}(\mathrm{~kg} \cdot \mathrm{h} / \mathrm{L})$ after a single oral dose of riociguat. In the first study, individuals with severe renal impairment (group 4) received riociguat $0.5 \mathrm{mg}$; all other participants in both studies received riociguat $1 \mathrm{mg}$. Box, 25-75th percentile; vertical line, 10th-90th percentile; horizontal line, median; more extreme values are plotted as points; individuals eligible for pharmacokinetic analysis, $n=63$; $A \cup C_{\text {norm, }}$ area under the plasma concentration-time curve from time 0 to infinity divided by dose per kilogram of body weight for total riociguat.

rapidly absorbed; median time to reach maximum concentration in plasma $\left(t_{\max }\right)\left(C_{\max }\right)$ was 1 hour in all four groups. Mean half-life of total riociguat was longer in groups 2-4 (9.5-11.4 hours) than in group 1 (6.2 hours) (Table 1), and renal clearance of riociguat decreased with decreasing renal function. Mean exposure to total riociguat (area under the concentration-time curve divided by dose per kilogram of body weight $\left[\mathrm{AUC}_{\text {norm }}\right]$ ) was $42.7-$ $104.3 \%$ higher in groups $2-4$ than in group 1 (Table 1 , Figure 1). However, exposure was highly variable in groups 2-4 and the exposure ranges in all groups overlapped (Figure 1). Exposure to riociguat did not increase strictly in parallel with decreasing $\mathrm{CL}_{\mathrm{CR}}$. Results for unbound riociguat and M1 were similar to those for total riociguat and M1. No serious or severe adverse events were reported. Headache was the most common drug-related adverse event. No changes in safety or tolerability were detected with decreasing $\mathrm{CL}_{\mathrm{CR}}$. Riociguat $\mathrm{C}_{\max }$ and $\mathrm{AUC}$ ranges in patients with renal impairment overlapped those previously observed in healthy volunteers and patients with $\mathrm{PH}[2,3]$.

\section{Conclusion}

Exposure to riociguat was higher in individuals with renal impairment $\left(\mathrm{CL}_{\mathrm{CR}} 15-80 \mathrm{~mL} / \mathrm{min}\right)$ than in controls; particular care should be exercised during individual dose titration in patients with renal impairment.

\section{Acknowledgements}

The studies were funded by Bayer Pharma AG, Wuppertal, Germany, and performed by Atef Halabi, Clinical Trial Director, CRS Clinical Research Services Kiel GmbH, Lornsenstrasse 7, 24105 Kiel, Germany.

\section{Authors' details}

${ }^{1}$ Clinical Pharmacology, Bayer Pharma AG, Pharma Research Centre, Wuppertal, Germany. ${ }^{2}$ Global Biostatistics, Bayer Pharma AG, Pharma Research Centre, Wuppertal, Germany.

\section{Published: 29 August 2013}

\section{References}

1. Stasch JP, Pacher P, Evgenov OV: Soluble guanylate cyclase as an emerging therapeutic target in cardiopulmonary disease. Circulation 2011, 123:2263-2273.

2. Frey R, Mück W, Unger S, Artmeier-Brandt U, Weimann G, Wensing G: Single-dose pharmacokinetics, tolerability and safety of the soluble guanylate cyclase stimulator BAY 63-2521; an ascending-dose study in healthy male volunteers. J Clin Pharmacol 2008, 48:926-934.

3. Grimminger F, Weimann G, Frey R, Voswinckel R, Thamm M, Bölkow D, Weissmann N, Mück W, Unger S, Wensing G, et al: First acute haemodynamic study of soluble guanylate cyclase stimulator riociguat in pulmonary hypertension. Eur Respir J 2009, 33:785-792.

4. Ghofrani HA, Hoeper MM, Halank M, Meyer FJ, Staehler G, Behr J, Ewert R, Weimann G, Grimminger F: Riociguat for chronic thromboembolic pulmonary hypertension and pulmonary arterial hypertension: a phase II study. Eur Respir J 2010, 36:792-799.

5. Ghofrani H, Galie N, Grimminger F, Humbert M, Keogh A, Langleben D, Kilama MO, Neuser D, Rubin L: Riociguat for the treatment of pulmonary arterial hypertension: a randomized, double-blind, placebo-controlled study (PATENT-1). Chest 2012, 142:1027A.

6. Ghofrani H, Grimminger F, Hoeper M, Kim N, Mayer E, Neuser D, Pena J, Simonneau G, Wilkins M: Riociguat for the treatment of inoperable chronic thromboembolic pulmonary hypertension: a randomized, double-blind, placebo-controlled study (CHEST-1). Chest 2012, 142:1023A. 
7. Hurdman J, Condliffe R, Elliot CA, Davies C, Hill C, Wild JM, Capener D, Sephton P, Hamilton N, Armstrong IJ, Billings C, Lawrie A, Sabroe I, Akil M, OToole L, Kiely DG: Aspire Registry: assessing the spectrum of pulmonary hypertension identified at a referral centre. Eur Respir J 2012, 39:945-955

8. Guidance for Industry. Pharmacokinetics in Patients with Impaired Renal Function - Study Design, Data Analysis, and Impact on Dosing and Labeling [[http://www.fda.gov/downloads/Drugs/

GuidanceComplianceRegulatoryInformation/Guidances/ucm072127.pdf]].

9. Note for Guidance on the Evaluation of the Pharmacokinetics of Medicinal Products in Patients with Impaired Renal Function [[http:// www.ema.europa.eu/docs/en_GB/document_library/Scientific_guideline/ 2009/09/WC500003123.pdf]].

doi:10.1186/2050-6511-14-S1-P22

Cite this article as: Frey et al:: Pharmacokinetics of the soluble guanylate cyclase stimulator riociguat in individuals with renal impairment. BMC Pharmacology and Toxicology 2013 14(Suppl 1):P22.

\section{Submit your next manuscript to BioMed Central} and take full advantage of:

- Convenient online submission

- Thorough peer review

- No space constraints or color figure charges

- Immediate publication on acceptance

- Inclusion in PubMed, CAS, Scopus and Google Scholar

- Research which is freely available for redistribution

Submit your manuscript at www.biomedcentral.com/submit
Ciomed Central 